\title{
MICRO-SPECIFIC PROFITABILITY FACTORS OF THE SERBIAN INSURANCE INDUSTRY: A PANEL DATA ESTIMATION
}

\section{Željko Vojinović1, Sunčica Milutinovićn ${ }^{2}$ Bojan Leković ${ }^{3}$}

\footnotetext{
1 University of Novi Sad, Faculty of Economics in Subotica, Department of Finance and Accounting, Republic of Serbia, zeljko.vojinovic@ef.uns.ac.rs;

2 University of Novi Sad, Faculty of Economics in Subotica, Department of Finance and Accounting, Republic of Serbia, suncica@ef.uns.ac.rs;

3 University of Novi Sad, Faculty of Economics in Subotica, Department for Management, Republic of Serbia, bojan.lekovic@ef.uns.ac.rs.
}

\begin{abstract}
The paper investigates the main micro-specific profitability determinants of the insurance industry in Serbia, covering the period 2008-2016. Data set includes accounting ratios for 19 universal insurers, officially reported by the National Bank of Serbia (NBS). We have estimated the fixed effects model using the OLS and GLM estimation procedures, with return on asset (ROA), return on equity (ROE) and return on total premium (ROTP) as the response variables. The estimated results from different models are quite consistent, with some minor deviations related mainly to the magnitude of the effects. Specifically, there is a trade-off between liquidity and profitability, and the insurance companies exploit economies of scale extensively. Loss and risk exposure have significant adverse effect on profitability, while productivity proved to be not significant. In addition, the relative market power (market position) and size have significant positive impact on profitability, while business specialization favors insurance over reinsurance, particularly the life-insurance business, as well as the business specialization dummies (insurance vs. reinsurance, life vs. nonlife insurance). Consequently, an optimal profitability strategy should be based on mergers and acquisitions, appropriate risk-taking and risk-management practices, and business sophistication through specialization. In addition, the companies should weight costs and benefits of keeping an excess of liquid reserves. The results also indicate further market concentration due to the size effects, and it could result in higher prices and lower quality of the services. This in turn imposes the new regulatory challenges in terms of the optimal antitrust strategy and appropriate quality control. The implications of these findings are applicable to other Western Balkan countries, especially to Bosnia and Herzegovina and Macedonia.
\end{abstract}

Keywords: Insurance market, profitability determinants, panel data estimation.

JEL Classification: G2, G22.

APA Style Citation: Vojinović, Ž., Milutinović, S., \& Leković, B. (2020). Micro-specific Profitability Factors of the Serbian Insurance Industry: A Panel Data Estimation. E\&M Economics and Management, 23(1), 135-155. https://doi.org/10.15240/tul/001/2020-1-010

\section{Introduction}

Risks, as the opportunity-threat combinations, are the ubiquitous factors of the modern business and life. As we transfer a portion of risks to the insurance companies, so they retransfer a fraction of risks to other insurers through reinsurance arrangements. These transfers produce both revenues and costs, and that is why profitability analysis is at the core of both performance management and supervisory treatment. It is worth noting the macroeconomic importance of the insurance industry too, since the insurance industry continues to grow, becoming an important part of the financial sector that contributes significantly to economic growth (Haiss \& Sümegi, 2008). On the contrary, 
the insurance market instability (liquidity crises, massive losses, etc.) can trigger financial sector disturbances and negative spillover effects, so that the insurance industry requires a kind of special supervisory treatment (Das, Davies, \& Podpiera, 2003). So, the importance of the study comes from the multidimensional importance of the insurance industry, focusing the firm-specific factors affecting profitability of the Serbian insurance sector.

Research problem encompasses the microspecific determinants of earnings, and it is dimensioned along the several line of influence through the risk exposure, loss control, and business specialization. Thus, the study challenges investment policy, risk attitude, marketing strategy and the corresponding profitability effects produced by the companylevel decision-making process. On the contrary, the study disregards the external profitability factors such as regulatory environment and economic growth, because those factors are uncontrollable variables from a single company standpoint. Such a research orientation brings us to the main goal of the paper: to identify the main company-specific profitability drivers and formulate an appropriate business strategy based upon the identified factors that contribute to the financial strength of the insurance companies.

The prespecified research goal allows us to derive several complementary research hypotheses the study aims to challenge. Namely, we explore whether liquidity and profitability are interrelated, as assumed by the economic theory. Besides, the study challenges the hypothesis of the size effects, implying that bigger companies acquire higher profit due to decreasing marginal costs. Also, we aim to prove that excessive risk exposure coupled with unacceptable high losses have detrimental profitability effects, since there is a market penalty for being a risky insurer (Cummins \& Nini, 2002). Finally, we test the hypothesis that business diversification destroys profitability flows and the value of the firm. In the operational sense, the last hypothesis implies testing whether business specialization (insurance vs. reinsurance; life vs. non-life insurance) contributes to profitability and value of the firm.

The study proceeds as follows. After a brief introductory note and theoretical background about the profitability measures, we present the most relevant empirical studies focusing implemented methodologies and main outcomes. The following section includes data description and methodological notes (model selection and estimation procedure). The third section discusses the results and implication, while the fourth part includes a cross-literature discussion with respect to the main findings. Finally, the last part concludes.

\section{Profitability Measures: Theoretical Background}

Profitability analysis of the insurance companies is at the core of performance management, having in mind that many stakeholders primarily focus financial performances (the financial ratios) derived from the balance sheet and income statement items (or their combinations). Specifically, the most important financial performance measures include return on asset (ROA), return of equity (ROE), while the most important insurance-specific profitability measure is return on total premium (ROTP). The ROA measures how many units of profit a company earns per unit of total assets, while ROE measures the unit of profit per unit of total equity. Comparatively speaking, it is widely accepted viewpoint that the ROA is a better (more precise and unbiased) measure of profitability, bearing in mind that total equity can be modified easily through the "creative accounting". However, we have to consider strong regulatory requirements that are usually imposed to the insurance sectors, and some of them are related to the capital requirements and solvency (see e.g. Kwon, Kim, \& Lee, 2005; Pope \& Ma, 2005; Chrysovalantis, Liuling, \& Fotios, 2015). Accordingly, the insurance companies do not have a wider scope for making up the financial result and capital structure, making the ROE more precise and objective relative to the non-financial companies. Moreover, regulations may also alter the structure and competition of the industry, constrain insurers' prices and products, and impose additional costs on firms Finally, the ROTP measures net profit per unit of total premium collected, and it reflects the core of the insurance business. Namely, the ROTP is mainly a function of the operational costs on one hand, and costs of the covered losses on the other hand.

Apart from the key profitability measures, the insurance companies' can monitor their financial strength by calculating additional financial ratios: (1) risk retention (net premium written/gross premium written), (2) loss ratio 
(net claims incurred/net premium earned), (3) expense ratio (management expenses plus commission fees/net premium earned), (4) investment yield (total interest income/total investments), (5) return on net worth (net profit/ net worth). In addition, we can monitor financial performances by calculating the market-based measures such as price-to-earning ratio $(P / E)$, book to market values, distance to default, etc. There are two reasons we have chosen the key accounting ratios as the dependent variables in the profitability model specification. First, it is not possible to calculate other profitability ratios due to data unavailability. Second, the marketbased ratios require a well-developed stock market that allows the insurance companies' shares to be traded, which is not the case in many developing countries including Serbia.

Finally, it is important to point out all the difficulties connected with any plausible profitability analysis. At first, it is usually based on different profitability measures that are rather incomparable than consistent. In addition, it involves directly or indirectly many stakeholders (insurers, supervisors, policyholders, etc.) with conflicting interests, so that the profitability indicators and analysis itself could be biased. Accordingly, the profitability analysis is more often controversial, because it always tries to find an effective modus operandi to reconcile those opposing influences. According to McClenahan (1995): "Measurement of profitability is to some extent, like beauty, in the eye of the beholder. The connotation of the word profitability is highly dependent upon who is assessing profitability and to what purpose. To investors and insurers, profitability has a golden ring to it. To policyholders of a stock insurer it sounds like markup, while to those insured by a mutual company it is neutral. Insurance regulators either encourage profitability, when concerned with solvency, or seek to curtail it, when regulating rates. The IRS seeks to inflate it and consumer groups seek to minimize it."

\section{Literature Overview}

Many recent empirical studies deal with the key profitability factors of the insurance industries worldwide, implying that this scientific field have attracted a lot of attention nowadays. A closer look at these studies reveal their common attributes in terms of methodology and data sample. Namely, most of the studies target period after the global crisis, but there are also studies that span to the previous years. In addition, a huge portion of papers deal with both static and dynamic panel estimates, and with two or more model specifications. Finally, most of them are country-based, although some authors pooled data from several countries to compare the profitability determinants across different insurance industries, both from developed and developing countries. A comprehensive literature survey that includes methods used and the most important results are presented in Appendix (see Tab. A1).

As for the developed insurance markets, Browne, Carson and Hoyt (2001) have designed the dynamic financial models of life insurers trying to determine the most important profitability drivers. Using empirical data for the period 1985-1995 they indicated several external profitability factors of the US insurance sector such as interest rate, personal income, unemployment and stock market movements. In addition, Shiu (2004) identifies the determinants of the performance of the United Kingdom general insurance companies using a panel data set and covering the period from 1986-1999. He finds that liquidity, unexpected inflation, interest rate and underwriting profit shape the performances of the UK insurers. Furthermore, Liebenberg and Sommer (2008) uses the standard panel data models (OLS and different treatment models) to explore the profitability effects of diversification among the US insurers, covering the period 1995-2004. They find diversification discount of 1 percent of return on assets (ROA) and 2 percent of return on equity (ROE). Consequently, the results support the strategic focus hypothesis. Furthermore, mutual insurers are significantly less profitable than stock insurers, while capitalization and size have positive effect on profitability. Finally, Berry-Stoelzle and Song (2015) estimates the two ordinary least regressions coupled with the treatment effect model for the US insurance sector, aiming at capturing the potential effects of diversification on firms' performance. The study covers the period from 1995 to 2004 and it finds that diversification does not destroy the value of the firm in general, which is contrary to the findings of Liebenberg and Sommer (2008).

There are many other empirical studies dealing with the emerging market countries, both from Asia and Europe, and those studies are more relevant to this research to 
a certain point, due to similar environmental factors that affect the insurance market. For example, Chen and Wong (2004) focus on the solvency of general (property-liability) and life insurance companies in many Asian countires (Japan, Singapore, Malaysia, Taiwan) using multivariate analysis (fixed effect model) and both firm and macro data separately. The results slightly differ for the general insurers comparing to the life insurers. Specifically, the profitability of the general insurers is greatly affected by firm size, investment performance, liquidity ratio, surplus growth, combined ratio, and operating margin. On the other hand, the profitability drivers among the life insurers are firm size, change in asset mix, investment performance and change in product mix. In another empirical investigation Lee (2014) has specified two profitability models to evaluate profitability determinants of the property-liability insurance companies in Taiwan, during the period 1999-2009. The paper employs the OLS, and both fixed effects and random effects model, allowing for the individual-specific differences among the companies. The results point out that profitability is significantly related to underwriting risk, reinsurance, input costs, and holding-group membership. Moreover, leverage is negatively associated with ROA, while market share is negatively associated with the operating ratio.

More recently, Dogan (2013) and Kaya (2015) have investigated independently the profitability determinants of the non-life insurance companies in Turkey in a multiple regression panel data setting over the periods 2005-2011 and 2006-2013, respectively. The former study includes the single profitability model, while the latter one sublimates two comparable panel models only for the non-life insurers, with the technical profitability and sales profitability ratios as the dependent variables. According to Dogan (2013), profitability (ROE) is negatively related to age, liquidity, loss and leverage, and positively related to size. Kaya (2015) has found somehow conflicting results, with the negative impact of age, loss ratio, and liquidity. On the other hand, the impact of size and premium growth is positive. Finally, Charumathi (2012) and Jerene (2016) specify the fixed effects dynamic profitability model of the insurance market in India covering the period 2008-2011 and 2006-2016, respectively. Charumathi (2012) finds that profitability is negatively affected by leverage, premium growth, and equity, and positively affected by the size and liquidity. On the contrary, Jerene (2016) reveals a positive impact of capital adequacy and GDP, and a negative impact of liquidity and inflation.

There are also many studies related to the profitability determinants among the European insurance industries, both from the EU members and the non-EU countries. Most of them are single-country studies, although we can find the examples of a multiple-country studies too. For example, Hrechaniuk et al. (2007) explore different micro-specific factors affecting profitability in Spain, Lithuania, and Ukraine within different timeframes, using random effect panel regression model. They argue in favor of significant impact of microeconomic factor on the insurers' financial performances in these countries, although there is a significant difference in the insurance market structure between them. Their results showed a strong correlation between insurers' financial performance and the growth of the written premium. In two independent studies Kozak (2011) and Ortyński (2016) examine the main driving factors (both external and internal) of the insurance sector profitability in Poland specifying a panel regression model. The first study uses a panel of 25 non-life insurance companies throughout the period 2002-2009, while the second study includes 8 the largest companies during the period 2006-2013. Kozak (2011) determines the portfolio restructuring, gross premium growth, cost cutting strategy, internationalization, and GDP as the main profitability drivers. On the other hand, Ortyński (2016) finds economics of scale effect, while the negative effects on profitability are proved for underwriting activity and operating expenses.

There are also several relevant studies that investigate profitability determinants of the insurance industries across the Western Balkan countries, those who share the same characteristics with the insurance sector of Serbia. Specifically, Pervan and Pavic Kramaric (2010) investigate the internal and external profitability determinants of the insurance sector of Croatia using a dynamic panel regression model, covering the period 2003-2009. The finds profitability trend as an autoregressive process, probably because of the accounting methodology that measures profit in subsequent periods. In addition, profitability of the Croatian 
insurers is negatively affected by the ownership structure, operative efficiency (measured by the expense ratio) and inflation. Unlike the previous study that deals with the non-life insurance market segment, Curak, Pepur and Popovski (2011) investigates profitability drivers among the composite insurers during the period 2004-2009 in a panel fashion. The regression profitability model includes not only firmspecific but also economy-wide factors. The estimated results show that size, underwriting risk, inflation and equity returns have significant impact on ROA. Additionally, Curak, Utrobicic and Kovac (2014) explore the determinants of the reinsurance in Croatia, employing a random effect panel model on the sample of 19 insurers, covering the period 2006-2011. They basically estimated a regression model of the reinsurance demand, and found leverage, size, ROI, ownership, and the non-life share as the important determinants of the reinsurance trends in Croatia.

In a panel dynamic framework, Pervan, Curak and Marjanovic (2012) analyzes factors influencing the insurance sector profitability in Bosnia and Herzegovina, covering the period 2005-2010. The paper employs a dynamic profitability model that is estimated using the GMM approach, to overcome potential endogeneity problem. To make the model dynamic, the list of independent variables includes a one-period lag of dependent variable (profitability ratio). The results revealed that the relative market position, past business performances and age play are driving factors of profitability. However, the results do not support the home-field advantage hypothesis, since the domestic companies are outperformed by the foreign ones. Finally, the relation between portfolio diversification and profitability is not statistically significant. To examine the factors that trigger the insurance sector profitability in Romania, Burca and Batrinca (2014) specify an extensive empirically-oriented profitability models (fixed effect and random effect models) for 21 insurance companies, covering the period 2008-2012. The Hausmann test was employed to determine the validity of the fixed effects vs. random effects specification, and the fixed effects is a winner in this case. As for the results, they found that the solvency margin, retention ratio, and size have significant positive impact, while leverage and underwriting risks have adverse profitability effects.
To our best knowledge, there is the only one relevant empirical study that deals with the profitability determinants of the insurance companies in Serbia. Namely, Kocovic, Paunovic and Jovovic (2014) investigate the profitability determinants of the non-life insurers in Serbia during the period 2006-2013. They formed a panel data set with 96 observation for 12 non-life insurance companies and used the CAMELS methodology and fixed effects regression model. The results suggest that the retention rate, leverage, and combined ratio are negatively associated with ROA, while company size, investment ratio, and premium growth are positively related to ROA. Finally, some variables such as age of a company, product diversification, and liquidity are not statistically significant.

Why we consider both studies for developed and developing insurance markets relevant for our research? The answer to this question stems from the inherited characteristics of the insurance market in Serbia. Namely, it passed through the transitional stage 25 years ago, but it was also significantly internationalized because many domestic companies were acquisitioned by the international strategic investors from the developed countries, mainly from the Western Europe. So, in terms of the managerial skills, organizational behavior and know-how, the micro-specific factors of the companies in Serbia could be comparable to those from their counterparts in developed countries. In addition, the Serbian economy receives economic impulses from the rest of the world through capital inflow, exchange rate and inflation, and global business fluctuations, meaning that the insurance market is indirectly affected by the global insurance trends. On the other hand, most of the employees and costumers (clients) come from the domestic market and share the same post-transitional values as the costumers in other posttransitional countries. The latter is especially true when it comes to the insurance markets in Croatia, Bosnia and Herzegovina, and Romania. Accordingly, the Serbian insurance market can be characterized as a hybrid market structure that shares the main features of the insurance sectors from both developed and emerging market economies.

Motivation for the study comes from the facts that there is only one comparable empirical study for Serbia, and very few of 
them (most of them are for Croatia) for the Western Balkan countries. Consequently, the area of profitability determinants of the insurance sector of Serbia can be considered significantly under-researched. The study by Kocovic, Paunovic and Jovovic (2014) deals only with the non-life insurers, while this study covers the whole market, including both life and non-life insurers. Moreover, the business specialization is one of the profitability determinants in our specification, and it has two relevant dimensions: (1) life and non-life market segments, (2) insurance and reinsurance. The importance of the paper comes from the managerial and supervisory implications derived from the results. By considering the results, the insurance companies should focus on the significant profitability determinants, aiming at improving underwriting activities, increasing the size, managing liquidity or diversifying their business operations. So, this study provides a basis for managers to build dynamic financial models for individual insurers. On the other hand, supervisors can use the results to detect the main drivers of financial strength of the companies, with the main goal to monitor specific business segments more closely to avoid potential systemic financial instabilities. Having in mind these considerations, we expect that the paper will contribute at least threefold: (1) we will add to the existing literature that deals with the Serbian insurance industry, (2) our profitability models include both life and non-life insurance companies, and can be considered more comprehensive, (3) our specification includes not only typical profitability drivers such as liquidity, loss ratio or size, but also the indicators of business specialization (life vs. non-life business, insurance vs. reinsurance).

\section{Data and Methodology}

The study is based on the balanced panel set of 19 insurance companies with total of 171 observations, covering the period 2008-2016. The data set includes yearly accounting ratios for majority of the Serbian insurance companies, although some new companies that entered the market in the meantime are excluded from the data. The performance indicators are calculated from the official NBS reports (NBS, 2008-2016). A comprehensive list of the companies, together with their main business indicators for the observed period is presented in Appendix (see Tab. A2). As we can see, there is a significant difference in profitability and liquidity among the insurance companies. Also, the market shares in both total asset and total market premium differ significantly, meaning that the market is moderately concentrated $(\mathrm{HHI}($ asset $)=1346, \mathrm{HHI}($ premium $)=1496)$. We use the standard profitability indicators: (1) return on asset (ROA), (2) return on equity (ROE), (3) return on total premium (ROTP), as the dependent variables. On the other hand, the

\section{Tab. 1: Dependent and independent variable}

\begin{tabular}{l|l|l|l}
\multicolumn{1}{c|}{ Variable } & \multicolumn{1}{c|}{ Mark } & \multicolumn{1}{c}{ Calculation } & \multicolumn{1}{c}{ Expected impact } \\
\hline Return on asset & ROA & Net-profit/Total asset & Dependent variable \\
\hline Return on equity & ROE & Net-profit/Equity & Dependent variable \\
\hline Return on total premium & ROTP & Net-profit/Total premium & Dependent variable \\
\hline Liquidity & LIQUID & Current asset/Short-term liabilities & Negative \\
\hline Loss-ratio & LOSS & Loss/Total premium & Negative \\
\hline Market penetration ratio & MPR & Total premium/Total market premium & Positive \\
\hline Productivity & PRODUCT & Total premium/Costs of workforce & Positive \\
\hline Risk exposure & RISK_EXP & Technical reserves/Total premium & Negative \\
\hline Size & SIZE & Ln (Total asset) & Positive \\
\hline Dummy 1 & DUMMY1 & 1 for insurance and 0 for reinsurance & Positive \\
\hline Dummy 2 & DUMMY2 & 1 for life and 0 for non-life insurance & Positive \\
\hline
\end{tabular}


list of independent variables includes liquidity, loss ratio, market penetration ratio, productivity, risk exposure, size and two dummies that capture business specialization (life vs. nonlife business, insurance vs. reinsurance). All the variables are calculated using annual insurance market reports officially published by the National Bank of Serbia, the institution that serves the supervisory role over the insurance market. The full list of the variables, calculation methodology, and the expected impact on the profitability are presented in the Tab. 1 .

To estimate the effects of covariates on the profitability indicators, we have specified three comparable profitability models. The generic version of the fixed effects panel regression model has the following form:

$$
y_{i, t}=\beta_{0}+\Sigma \beta_{i, t} X_{i, t}+\alpha_{i}+u_{i, t},
$$

where $X_{i}$ is a vector of independent variables, $\alpha_{i}$ is the unobserved time-invariant individual effect, while $u_{i, t}$ is an error term. Having in mind our explanatory and response variables, we have specified three comparable profitability models:

$$
\begin{aligned}
& \text { Model 1 } \\
& \text { ROA }_{i, t}=\beta_{0}+\beta_{1} \text { LIQUID }_{i, t}+\beta_{2} \text { LOSS }_{i, t}+ \\
& +\beta_{3} \Delta M P R_{i, t}+\beta_{4} \text { PRODUCT }_{i, t}+ \\
& +\beta_{5} \text { RISK }_{i, t}+\beta_{6} \operatorname{SIZE}_{i, t}+\beta_{7} D U M M Y 1_{i, t}+ \\
& +\beta_{8} \operatorname{DUMMY}_{i, t}+\alpha_{i}+u_{i, t}
\end{aligned}
$$

$$
\begin{aligned}
& \text { Model } 2 \\
& \text { ROE }_{i, t}=\beta_{0}+\beta_{1} \text { IIQUID }_{i, t}+\beta_{2} \text { LOSS }_{i, t}+ \\
& +\beta_{3} \Delta M P R_{i, t}+\beta_{4} \text { PRODUCT }_{i, t}+ \\
& +\beta_{5} \text { RISK }_{i, t}+\beta_{6} \operatorname{SIZE}_{i, t}+\beta_{7} D U M M Y 1_{i, t}+ \\
& +\beta_{8} D U M M Y 2_{i, t}+\alpha_{i}+u_{i, t}
\end{aligned}
$$

\section{Model 3}

ROTP $_{i, t}=\beta_{0}+\beta_{1}$ LIQUID $_{i, t}+\beta_{2}$ LOSS $_{i, t}+$ $+\beta_{3} \Delta M P R_{i, t}+\beta_{4} P_{R O D U C T_{i, t}}+$

$+\beta_{5}$ RISK $_{i, t}+\beta_{6} \operatorname{SIZE}_{i, t}+\beta_{7} D U M M Y 1_{i, t}+$

$+\beta_{8} D U M M Y 2_{i, t}+\alpha_{i}+u_{i, t}$,

where the profitability indicators are considered response variables, the set of micro-specific parameters are the explanatory variables, and the error terms $\left(u_{i, t}\right)$ are the factors out of the model.

According to the Hausmann test results for 7 Chi-square degrees of freedom (Model 1: Chi-square 15.567, p-value $=0.029 ;$ Model 2: Chi-square 17.016, $p$-value $=0.017$; Model 3 :
Chi-square 19.533, p-value $=0.006$ ), we reject the null hypothesis that the preferred model is the random effects model. Alternatively, we accept the alternative hypothesis and estimate the fixed effects model. The models are estimated using the OLS and GLM methodologies at least for two reasons. First, most of the comparable studies use the ordinary least squares approach for the same/similar type of the analysis (for example Liebenberg \& Sommer, 2008; Kocovic, Paunovic, \& Jovovic, 2014; Berry-Stoelzle \& Song, 2015). Second, in the context of the GLMs (generalized linear models), OLS is considered a special case of GLM, while the latter is considered a kind of extension of OLS. Namely, the distribution of the OLS error terms is gaussian, and the identity function is the link function. On the other hand, generalized linear models allow for different error distributions and different nature of the relationship between the independent variables and the dependent variable. So, having in mind different assumptions imposed on the error terms distribution, we want to estimate both OLS and GLM to make our results more robust to assumed distributional properties of the error terms. Alternatively, we could not estimate either difference in difference (treatment effects) or GMM model, having in mind that these specifications requires more precise data set (and instruments) that are not available in this case.

The OLS estimation is justified by the additional residual diagnostics with respect to heteroskedasticity, autocorrelation and normality of distribution. Namely, we have tested heteroskedasticity using the panel cross-sectional LR test, based upon the fitted values. Also, the autocorrelation is tested using the Breusch-Godfrey serial correlation LM test, while the i. i. d. assumption is additionally tested by plotting the residuals' autocorrelation function up to the lag 30 . We also perform the stability test using the Quandt-Andrews unknown breakpoint test, which is based on a single Chow Breakpoint Test performed at every observation between two dates, or observations. The test explores whether there is a structural change in all of the equation parameters. It compares the sum of squared residuals obtained by fitting a single equation to the entire sample with the sum of squared residuals obtained when separate equations are fit to each subsample of the data. As 
for the estimation procedure, it follows the standard econometric approach, starting from the descriptive analysis (descriptive statistics, correlation and covariance matrices), trough stationary testing (Tab. A4) and modeling and estimating coefficients, ending up with the Wald statistics (Tab. A5). Basically, the Wald test has challenged the null hypothesis that the estimated coefficients are all equal to zero, comparing to the alternative hypothesis stating that the coefficients significantly differ from zero. Finally, we have also provided the residual diagnostics (heteroskedasticity, serial correlation, and i. i. d. assumption check) in Appendix.

\section{Results}

The descriptive analysis results that include descriptive statistics, correlation and covariance matrices is presented in Appendix (see Tab. A3, Tab. A4, Tab. A5). The descriptive analysis tells us several important things: (1) ROE and ROTP are highly volatile comparing to ROA, (2) the profitability indicators mean spans from 0.9 to $14 \%$, while median spans from 1.4 to $9 \%$, (3) productivity ratio and risk exposure are extremely volatile, liquidity is moderately changing, while the parameter that captures size (log of total asset) is quite stable over the years, (4) only ROA and ROTP on one hand, productivity (PRODUCT) and market penetration ratio (MPR) on the other hand, are highly correlated ( 0.8 and 0.7 are the correlation coefficients, respectively).

As we have mentioned in the previous chapter, the empirical investigation follows the standard econometric procedure, including stationarity testing. To make the results more plausible, we run several stationarity tests including Augmented DF test, Levin, Lin \& Chu test, Im, Pesaran and Shin W-stat, and PP Fisher Chi-square. The full stationarity testing results are provided in Appendix (see Tab. A6). As we can see, some variables are stationary at level such as the profitability indicators, loss and productivity ratio. On the other hand, majority of independent variables are non-stationary at level, implying that they should be transformed and then included in the regression analysis. Accordingly, the stationarity checking proved that most of the independent variables are difference stationary, because the test proved

\section{Tab. 2: Model 1 (ROA) estimated results}

\begin{tabular}{|c|c|c|c|c|c|c|c|}
\hline \multirow{2}{*}{ Variable } & \multicolumn{3}{|c|}{ OLS } & \multirow{2}{*}{ Variable } & \multicolumn{3}{|c|}{ GLM (QHC)* } \\
\hline & Coeff. & Std. Err. & Prob. & & Coeff. & Std. Err. & Prob. \\
\hline LIQUID & -0.0286 & 0.0044 & 0.0000 & LIQUID & -0.0370 & 0.0042 & 0.0000 \\
\hline LOSS & -0.0125 & 0.0040 & 0.0018 & Loss & -0.0284 & 0.0044 & 0.0000 \\
\hline MPR & 0.2672 & 0.0002 & 0.0000 & MPR & 0.2502 & 0.0141 & 0.0000 \\
\hline PRODUCT & -0.0001 & 0.0006 & 0.8416 & PRODUCT & -0.0441 & 0.0301 & 0.1425 \\
\hline RISK_EXP & -0.3634 & 0.0871 & 0.0000 & RISK & -0.3684 & 0.1025 & 0.0004 \\
\hline SIZE & 0.2374 & 0.1129 & 0.0371 & SIZE & 0.2206 & 0.0571 & 0.0001 \\
\hline DUMMY1 & 0.7003 & 0.3113 & 0.0254 & DUMMY1 & 0.6737 & 0.3131 & 0.0325 \\
\hline DUMMY2 & 0.8004 & 0.3594 & 0.0274 & DUMMY2 & 0.7634 & 0.1913 & 0.0001 \\
\hline R-Squared & 0.3627 & Mean Dep. V. & 1.4167 & R-Squared & 0.3308 & Mean Dep. V. & 1.4167 \\
\hline Adj. R-sq. & 0.3546 & S. D. Dep. V. & 11.1202 & Adj. R-sq. & 0.3193 & S. D. Dep. V. & 11.1202 \\
\hline S. E. of Reg. & 2.4431 & Akaike info & 4.6410 & S. E. of Reg. & 2.5675 & Akaike info & 4.7445 \\
\hline
\end{tabular}

Source: own calculation

Note: * Generalized Linear Model (Quadratic Hill Climbing); Dispersion computed using Pearson Chi-Square; Coefficient covariance computed using observed Hessian. 
stationarity at the first-difference. We have taken this fact into consideration and included the differenced variables into the empirical profitability models.

The results of econometric modelling are presented in the following tables, separately for each pre-specified profitability model.

Tab. 2 presents the estimated results for the Model 1 (ROA is the dependent variable). All variables are statistically significant, except the productivity ratio (PRODUCT). Specifically, higher liquidity ratio implies lower profitability, meaning that companies must optimize between the liquid asset and short-term liabilities. So, we have proved the expected liquidity-profitability trade-off, implying that these performance measures should be considered an integral part of the performance management. Specifically, by increasing liquidity buffers, the insurance companies must sacrifice profitability to a certain level, and this fact provides the new insight into the effects of the supervisory interventions into the liquidity standards. In addition, the ROA is negatively affected by the loss and risk exposure ratios, and these findings have important implications for the investment policy. Namely, an inadequate risk-taking practice characterized by the excessive risk exposure would hurt profitability. This imposes a need for the precautionary measures in terms of a more conservative investment policies, although wellbalanced risk-taking activities are, in general, necessary in the insurance business. Also, a sound risk-taking practice coupled with the appropriate loss control should be considered and additional integral part of the performance management.

Since the Serbian insurance market is dominated by a few leading market players, it is expectable to have a relative market power as a significant profitability determinant. The estimated results just prove this assumption, having in mind that the market penetration ratio, measured by the share in total market premium, has very strong positive effect in ROA. It seems that "the bigger the better" assumption is correct, meaning that the companies can increase their financial performances by increasing their market power. However, we have to be aware the fact that the insurance market is monitored constantly by the National Bank of Serbia, and that this strategy of the oversized market dominance would be counteracted by the regulatory measures. In accordance with the previous finding, the regression results reveal that the companies exploit the economies of scale effect, bearing in mind that the size (measured by total asset) have strong positive impact on ROA. This finding suggests that a potential profitability strategy would be size-based, taking into account the market expansion opportunities in line with the regulatory guidelines regarding the market concentration. Also, this strategy of market expansion is a kind of double-edged sword, if we include into the analysis detrimental effects of excessive risk-taking practice and loss exposure.

We will get another flavor with respect to the ROA determinants, if we include the effects of business specializations, both at the level of life and non-life specialization, as well as the level of insurance and reinsurance business orientation. Namely, both specialization dummies have significant effects on ROA, implying that companies should specialize and serve a narrow market segment. Specifically, the companies that focus insurance over reinsurance, as well as companies that focus life over non-life insurance, have on average higher ROA. Overall, an adequate risk control coupled with market expansion within a specialized market segments (insurance in general and particularly life insurance) would be an appropriate profitability strategy. Of course, it would also include an appropriate management of the regulatory requirements, in line with the liquidity and solvency directives created by the EU regulators, since Serbia is currently in the process of the EU association.

Comparatively speaking, the results are consistent for both the OLS and GLM estimations, while the magnitude of the effects of specific determinants on ROA are slightly different. Namely, the negative effect of liquidity is slightly bigger in the GLS estimation, while the effects of market penetration, size and business specializations are slightly bigger in the OLS estimation. Also, the explanatory power of the OLS estimation is slightly bigger, bearing in mind the adjusted R-squared. Namely, the GLS estimation explains around $32 \%$ of variation in $\mathrm{ROA}$, and the difference with the OLS estimation comes from different asymptotic properties of the two estimators, both in terms the error terms distribution and multivalued relations between the dependent and independent variables. It is also worth noting that the adjusted R-squared is not so informative in panel data setting 
due to heterogeneity of the cross-sections. It seems that our data set is more cross section dominant, which resulted in lower adjusted coefficient of determination. So, we may not be able to explain across companies the overall level of earnings very accurately, but we might very accurately be able to measure the effect of specified profitability determinants. The results of the comparable profitability model that measures the effects on return to equity (ROE) are presented in Tab. 3 .

Tab. 3 shows the estimated results for the Model 2, where return on equity (ROE) is a dependent variable. Comparing to the ROA profitability model, we have obtained consistent results since the significance and direction of the causalities correspond to the previous case. However, the difference in magnitude of the effects of selected covariates are obvious, and it will be explained in the cross-model analysis at the end of this chapter. We also obtained consistent results for two competing methodologies (OLS and GLM), while the magnitude of the impact of selected covariates slightly differs. Namely, the negative loss effects are more pronounced in the OLS estimation, while the adverse risk-exposure effects are more intense in the GLS estimation. In addition, the OLS estimation measures slightly higher size and business specialization effects. Finally, the low adjusted coefficient of determination does not necessarily mean the low explanatory power of the model. It could be the case that we have here even more cross section dominance and pronounced cross-section heterogeneity.

The results also bring in interesting performance management recommendations, though analogous to the conclusions drawn for the ROA profitability model. Specifically, there is a trade-off between liquidity and profitability, implying that managers should reconcile conflicting preferences over strong liquidity buffers on one hand, and satisfiable profitability levels on the other hand. In addition, an effective risk-management and loss control policies are rewarding. Finally, the insurance market provides a significant profitability discount for business sophistication and penetration of narrowed market niches (insurance and life insurance). The results of the profitability model where return to total premium are chosen as a dependent variable are presented in Tab. 4 .

Tab. 3: Model 2 (ROE) estimated results

\begin{tabular}{|c|c|c|c|c|c|c|c|}
\hline \multirow{2}{*}{ Variable } & \multicolumn{3}{|c|}{ OLS } & \multirow{2}{*}{ Variable } & \multicolumn{3}{|c|}{ GLM (QHC)* } \\
\hline & Coeff. & Std. Err. & Prob. & & Coeff. & Std. Err. & Prob. \\
\hline LIQUID & -0.0703 & 0.0228 & 0.0023 & LIQUID & -0.0783 & 0.0256 & 0.0025 \\
\hline LOSS & -0.2925 & 0.0896 & 0.0013 & LOSS & -0.2504 & 0.0966 & 0.0105 \\
\hline MPR & 0.0896 & 0.0203 & 0.0000 & MPR & 0.0842 & 0.0226 & 0.0002 \\
\hline PRODUCT & -0.2117 & 0.2209 & 0.3390 & PRODUCT & -0.0336 & 0.0228 & 0.1421 \\
\hline RISK & -0.6092 & 0.2121 & 0.0045 & RISK & -0.7730 & 0.3188 & 0.0161 \\
\hline SIZE & 0.6713 & 0.2721 & 0.0143 & SIZE & 0.6588 & 0.2851 & 0.0218 \\
\hline DUMMY1 & 1.1719 & 0.1694 & 0.0000 & DUMMY1 & 0.9409 & 0.0264 & 0.0000 \\
\hline DUMMY2 & 0.3634 & 0.0311 & 0.0000 & DUMMY2 & 0.3430 & 0.0189 & 0.0000 \\
\hline R-Squared & 0.1664 & Mean Dep. V. & 14.2657 & R-Squared & 0.2043 & Mean Dep. V. & 14.2657 \\
\hline Adj. R-sq. & 0.1557 & S. D. Dep. V. & 40.9332 & Adj. R-sq. & 0.1907 & S. D. Dep. V. & 40.9332 \\
\hline S. E. of Reg. & 2.8594 & Akaike info & 4.9557 & S. E. of Reg. & 2.7995 & Akaike info & 4.9176 \\
\hline
\end{tabular}

Source: own calculation

Note: * Generalized Linear Model (Quadratic Hill Climbing); Dispersion computed using Pearson Chi-Square; Coefficient covariance computed using observed Hessian. 
Tab. 4: Model 3 (ROTP) estimated results

\begin{tabular}{l|c|c|c|l|c|c|c}
\multirow{2}{*}{ Variable } & \multicolumn{3}{|c|}{ OLS } & \multirow{2}{*}{ Variable } & \multicolumn{3}{c}{ GLM (QHC) } \\
\cline { 2 - 3 } \cline { 8 - 9 } & Coeff. & Std. Err. & Prob. & & Coeff. & Std. Err. & Prob. \\
\hline LIQUID & -0.1918 & 0.0851 & 0.0251 & LIQUID & -0.1410 & 0.0480 & 0.0037 \\
\hline LOSS & 0.0397 & 0.0961 & 0.6800 & LOSS & -0.0144 & 0.0205 & 0.4843 \\
\hline MPR & 0.1435 & 0.0216 & 0.0000 & MPR & 0.2174 & 0.0112 & 0.0000 \\
\hline PRODUCT & -0.0986 & 0.0829 & 0.2355 & PRODUCT & -0.0800 & 0.0556 & 0.1517 \\
\hline RISK & -0.2090 & 0.0990 & 0.0359 & RISK & -0.1719 & 0.0719 & 0.0177 \\
\hline SIZE & 0.8279 & 0.1123 & 0.0000 & SIZE & 0.5508 & 0.2169 & 0.0118 \\
\hline DUMMY1 & 0.9334 & 0.2597 & 0.0004 & DUMMY1 & 0.9550 & 0.0239 & 0.0000 \\
\hline DUMMY2 & 0.3455 & 0.0131 & 0.0000 & DUMMY2 & 0.3143 & 0.0191 & 0.0000 \\
\hline
\end{tabular}

\begin{tabular}{l|r|l|r|l|l|l|r}
\hline R-Squared & 0.2749 & Mean Dep. V. & 0.9036 & R-Squared & 0.2374 & Mean Dep. V. & 0.9036 \\
\hline Adj. R-sq. & 0.2625 & S. D. Dep. V. & 50.6013 & Adj. R-sq. & 0.2276 & S. D. Dep. V. & 50.6013 \\
\hline S. E. of Reg. & 2.6725 & Akaike info & 4.8247 & S. E. of Reg. & 2.7349 & Akaike info & 4.8667 \\
\hline
\end{tabular}

Source: own calculation

Tab. 4 shows the ROTP profitability determinants. Comparing to the previous results, the loss ratio is statistically insignificant in this specification, while other results provide similar conclusions. Specifically, the liquidityprofitability trade-off is indisputable, while the companies exploit market power extensively to boost return to premium. We also have a well-documented economies of scale effect, implying that a unit increase in size measure will produce and increase of ROTP for 0.06 (GLM) and 0.08 (OLS). The size effect is so important if we know that the average ROTP for all the companies is 0.9 . Finally, the market rewards business specialization in both dimensions, toward the general insurance and particularly life-insurance segment. Overall, an effective profitability management comes down to the effective risk management, size optimization, and business specialization, coupled with the optimal liquidity-profitability trade-off. The same conclusion with respect to both, the explanatory power of the model and cross-methodology comparison, also applies here.

It is also important to identify the implications for the insurance market, as well as the most important distinctions among the models. We can expect the market to be more concentrated, as the companies become bigger, aiming at exploiting the economies of scale. It will also affect the supervisory practice, since more concentrated market requires stronger regulatory measures with respect to capital requirements and solvency. The crossmodel comparison suggests that the Model 1 and Model outperform the Model 2 in terms of the explanatory power, although adjusted coefficient of determination is not as informative in panel data setting as in the time series one. In addition, lower explanatory power could be caused by the data set structure, while the lower explanatory power among the two competing methodologies arises from different asymptotic properties of OLS and GLM. The liquidity-profitability trade-off is the most significant in Model 3, and the least significant in Model 1. Accordingly, this difference requires different approach analogous to different priorities given to selected profitability ratios. Although the loss ratio is not significant variable in Model 3, an optimal profitability strategy includes management of loss exposure. In addition, the relative market power provides significant reward generally, but the market dominance creates the highest effect on ROA. The risk exposure hast the most obvious 
detrimental effects on ROE, although other two profitability indicators are also greatly hurt by the risk overexposure. All three models that the companies exploit economies of scale, but the size effects are the highest in Model 3. Finally, business specialization results in higher profitability, and the general recommendation is to specialize to life insurance and avoid reinsurance. The insurance specialization effects are the highest in Model 1, while the lifeinsurance specialization effects are the highest in Model 1.

Apart from the effects of different methodologies, the observed model-based differences are related to the differences between the profitability ratios. Namely, as long as variations in total asset, equity and total premium are pronounced, we will have significantly different accounting ratios and corresponding regression results. Finally, comparing to the expected impact (see Tab. 2), the estimated results just slightly differ with respect to productivity. Namely, productivity does not have significant impact on either profitability ratios, while other estimated causalities are in line with the expectations.

Lastly, it is important to justify the plausibility of the results by providing the residual diagnostics of the OLS estimation, having in mind that it relies on quite restrictive asymptotic properties. At the critical level of $5 \%$ we failed to reject the null hypothesis that the residuals are homoscedastic, as stated by the panel crosssectional LR test (Model 1: Value $=9.373764$, $p$-value $=0.9667 ;$ Model 2: Value $=10.0502$, $p$-value $=0.9517 ;$ Model 3: Value $=9.547042$, $p$-value $=0.9632)$. Accordingly, all residuals are drawn from a population that has a constant variance (homoscedasticity). In addition, we strongly failed to reject the null hypothesis of no serial correlation, as assumed by the Breusch-Godfrey serial correlation LM test (Model 1: F-stat $=0.633121, p$-value $=0.5322$; Model 2: F-stat $=0.014377, p$-value $=0.9857$; Model 3: F-stat $=0.01521, p$-value $=0.9849$ ) To prove the finding that the residuals are not serially correlated, we provide the ACFs of the residuals in Appendix (see Fig. A1). All three ACFs fit within the boundaries, except the Model 2 ACF for the lag 15 which slightly breaks the lower bound. Since this is a unique case after several lags, the pure randomness should be accounted for such outcome. Accordingly, the residuals are independent identically distributed, and our OLS estimations should be considered plausible. Furthermore, we run the Wald test to challenge the null hypothesis that regression coefficients are not significantly different from zero. The full set of the results for each profitability model is presented in Appendix (see Tab. A7). As we can see, we reject the null hypothesis for each regression coefficient for all three models, meaning that the estimated coefficients are not zero. Finally, we failed to reject the null hypothesis of the Quandt-Andrews unknown breakpoint test, implying that there are no structural breakpoints in the sample for a specified equation (Model 1: Exp LR F-statistic $=0.45076, p$-value $=0.7863$; Model 2: Exp LR F-statistic $=0.61139$, $p$-value $=0.4681 ;$ Model 3: 0.234183 , $p$-value $=0.9893$ )

\section{Discussion}

This section focuses a cross-literature analysis with respect to the same/similar and contrasting results regarding the insurance sector profitability determinants. Namely, some of the results are completely in line with the surveyed empirical studies, while others contradict sharply. Specifically, statistical insignificance of the productivity ratio implies that either our measure does not capture the productivity effects or the insurance companies' workforce is defined differently. The proved liquidityprofitability trade-off we find in other empirical studies (Dogan, 2013; Kaya, 2015; Jerene, 2016). On the contrary, numerous studies reveal no significant relationship between the liquidity and profitability ratios (Ahmed et al., 2011; Malik, 2011; Mehari \& Aemiro, 2013; Kocovic, Paunovic, \& Jovovic, 2014), while other studies argue in favor of a positive liquidity-profitability linkage (Al-Soub, 2012; Bawa \& Chatta, 2013). The divergent results can be explained by different sample and/ or different empirical methodologies. Namely, market forces and external environment of each insurance sector are unique to a certain point, and the balance sheets of the companies are shaped by different regulatory standards.

The empirical evidences of the profitability effects of risk exposure and loss are quite coherent, as many studies suggest detrimental effects of uncontrolled risk exposure and consequent losses on financial strength of the insurance companies (Malik, 2013; Dogan, 2013; Kaya 2015). In addition, the size 
measures that represent relative market power proved to be significant profitability drivers in most of the cases. For example, these findings are in line with the evidences provided by Barca and Batrinca (2014), Kocovic, Paunovic and Jovovic (2015), and Kaya (2015). It is worth nothing that our study relies not only on size but also on market penetration ratio as a measure of relative market power, aiming at separating the effects that come from cost efficiency and relative market power. Finally, our results support specialization toward insurance, especially life insurance business. The evidences indirectly support the findings of Liebenberg and Sommer (2008), Adams, Hardwick and Zou (2008), and Moro and Anderloni (2014), and contrast the results of Berry-Stoelzle and Song (2015).

\section{Conclusion}

The paper investigates the main micro-specific factors that drive profitability of the insurance industry in Serbia. We have estimated a fixed effects model using the OLS and GLS methodologies on the panel data set of 19 insurance companies. The study covers the period 2008-2016 and uses widely accepted profitability indicators (ROA, ROE, ROTP) as dependent variables. The results prove a decisive impact of profitability, risk exposure, size and business specialization (insurance over reinsurance; life over non-life insurance) on profitability.

These findings should be appropriately reflected in the optimal business strategies and prudent supervisory practice. Specifically, to increase profitability managers should focus on a refined liquidity management and risk exposure control. Also, to exploit relative market power the companies should plan their market expansion through mergers and acquisitions. Finally, an optimal profitability strategy requires a well-defined business profile appropriately tailored for specialized market niches, primarily for the life insurance niche. How these trends would affect the market? Since the size matters, we can expect the market to become more concentrated which will create further regulatory challenges. Namely, an overconcentrated insurance market is particularly vulnerable to systemic financial crises, and the supervisory bodies must respond with stronger capital requirements and risk control mechanisms. Besides, the market would move from the price-taking infrastructure to the oligopolistic one, implying higher average prices and lower quality of the services. Thus, the National Bank of Serbia should create an optimal antitrust regulatory framework, coupled with a sensitive mechanism of the quality control.

Since the study focuses the firm-specific profitability determinants, the findings and policy implications are transferable at least to other Western Balkan countries such as Croatia, Bosnia and Herzegovina, Macedonia, and Romania. The justification lies in the fact that those insurance markets are shaped by the same international strategic investors. However, we have to keep in mind that some of the countries are already EU members, and their insurance sectors are subject to unified EU supervision. Accordingly, the supervisory practices in Croatia and Romania are mainly guided by the insurance-related EU Directives.

\section{References}

Adams, M., Hardwick, P., \& Zou, H. (2008). Reinsurance and corporate taxation in the United Kingdom life insurance industry. Journal of Banking \& Finance, 32(1), 101-115. https://doi.org/10.1016/j.jbankfin.2007.09.006

Ahmed, N., Ahmed, Z., \& Usman, A. (2011). Determinants of Performance: A Case of Life Insurance Sector in Pakistan. International Research Journal of Finance and Economics, 61, 123-128.

Almajali, A., Sameer, A. A., \& Al-Soub, Y. Z. (2012). Factors affecting the financial performance of Jordanian insurance companies listed at Amman stock exchange. Journal of Management Research, 4, 266-289. http://dx.doi.org/10.5296/jmr.v4i2.1482

Bawa, S., \& Chattha, S. (2013). Financial performance of life insurers in Indian insurance industry. Pacific Business Review International, 6(5), 44-52.

Berry-Stoelzle, R. T., \& Song, I. J. (2015). Effects of Corporate Diversification Revisited: New Evidence from the Property-Liability Insurance industry. Retrieved from The World Risk and Insurance Economics Congress (WRIEC). https://doi.org/10.1146/annurevfinancial-121415-032815

Browne, M., Carson, J. M., \& Hoyt, R. E. (2001). Dynamic financial models of life insurers. North American Actuarial Journal, 5(2), 11-26. https://doi.org/10.1080/10920277. 2001.10595981 
Burca, A.-M., \& Batrinca, G. (2014). The Determinants of Financial Performance in the Romanian Insurance Market. International Journal of Academic Research in Accounting, Finance, and Management Science, 4, 299-308. https://doi.org/10.6007/IJARAFMS/v4-i1/637

Charumathi, B. (2012). On the Determinants of Profitability of Indian Life Insurers - An Empirical Study. In Proceedings of the World Congress on Engineering, Vol. I. London, U. K. Retrieved from http://www.iaeng.org/ publication/WCE2012/WCE2012_pp505-510.pdf

Chen, R., \& Wong, K. A. (2004). The determinants of financial health of Asian insurance companies. Journal of Risk and Insurance, 71(3), 469-499. https://doi. org/10.1111/j.0022-4367.2004.00099.x

Gaganis, C., Liu, L., \& Pasiouras, F. (2015). Regulations, profitability, and risk-adjusted returns of European insurers: An empirical investigation. Journal of Financial Stability, 18, 55-77. https://doi.org/10.1016/j.jfs.2015.03.001

Cummins, D., \& Nini, G. (2002). Optional Capital Utilization by Financial Firms: Evidence from the Property-Liability Insurance Industry. Journal of Financial Services Research, 21(1), 15-53. https://doi. org/10.1023/A:1014369617192

Curak, M., Pepur, S., \& Poposki, K. (2011). Firm and Economic Factors and Performance: Croatian Composite Insurers. The Business Review Cambridge, 19(1), 136-142.

Curak, M., Utrobicic, M., \& Kovac, D. (2014). Firm-specific characteristics and reinsurance Evidence from Croatian insurance companies. Economic Thought Practice, 1, 29-42.

Das, U. S., Podpiera, R., \& Davies, N. (2003). Insurance and issues in financial soundness (Working paper No. 3-138). Washington: International Monetary Fund.

Doğan, M. (2013). Relations between the profitability and capital structure of insurance companies: An analysis over Turkish capital market. Journal of Accounting and Finance, 57, 121-136.

Pasiouras, F., \& Gaganis, C. (2013). Regulations and soundness of insurance firms: International evidence. Journal of Business Research, 66(5), 632-642. https://doi. org/10.1016/j.jbusres.2012.09.023

Haiss, P., \& Sümegi, K. (2008). The relationship between insurance and economic growth in Europe: a theoretical and empirical analysis. Empirica, 35(4), 405-431. https://doi. org/10.1007/s10663-008-9075-2
Hrechaniuk, B., Lutz, S., \& Talavera, A. (2007). Do Determinants of Insurers' Performance Differ in Old EU, the New EU and Outside. University of Bonn and University of Manchester.

Jerene, W. (2016). Factors affecting general insurance companies' profitability: Empirical study in India. International Journal of Marketing, Financial Services \& Management, 5, 1-8.

Kozak, S. (2011). Determinants of profitability of non-life insurance companies in Poland during integration with the European financial system. Electronic Journal of Polish Agricultural Universities, 14(1), 1-9.

Kwon, W. J., Kim, H., \& Lee, S. J. (2005). Can insurance firms easily exit from the market? A global comparative analysis of regulatory structures. The Geneva Papers on Risk and Insurance-Issues and Practice, 30(2), 268-284. http://doi.org/10.1057/palgrave.gpp.2510024

Lee, C. Y. (2014). The effects of firm specific factors and macroeconomics on profitability of property-liability insurance industry in Taiwan. Asian Economic and Financial Review, 4(5), 681-691.

Liebenberg, A. P., \& Sommer, D. W. (2008). Effects of corporate diversification: Evidence from the property-liability insurance industry. Journal of Risk and Insurance, 75(4), 893-919. https://doi.org/10.1111/j.15396975.2008.00290.x

Malik, H. (2011). Determinants of insurance companies profitability: an analysis of insurance sector of Pakistan. Academic Research International, 1(3), 315-321.

Mehari, D., \&Aemiro, T. (2013). Firm Specific Factors that Determine Insurance Companies' Performance in Ethiopia. European Scientific Journal, 9(10). http://dx.doi.org/10.19044/ esj.2013.v9n10p\%25p

Moro, O., \& Anderloni, L. (2014). Nonlife insurance Economic Performances - An Empirical Investigation. Journal of Economics \& Management, 18, 159-177.

National Bank of Serbia. (2016). Insurance Sector in Serbia (Reports for 2007-2016). Belgrade: National Bank of Serbia.

National Bank of Serbia. (2009). Banking Supervision: Second Quarter Report 2009. Belgrade: National Bank of Serbia.

National Bank of Serbia. (2018). Insurance Companies Operations. Retrieved January 15, 2018, from https://www.nbs.rs/internet/ english/60/60_2/index.html 
Ortyński, K. (2016). Determinants of profitability of general insurance companies performance in Poland. Central European Review of Economics \& Finance, 12(2), 53-66.

Pervan, M., \& Pavic Kramaric, T. (2010). Determinants of Insurance Companies' Profitability in Croatia. The Business Review Cambridge, 16(1), 231-238.

Pervan, M., Curak, M., \& Mariajnovic, I. (2012). Dynamic panel analysis of B\&H insurance companies' profitability. Recent Researches in Business and Economics, 158-163.
Pope, N., \& Ma, Y. L. (2005). Market Deregulation and Insurer Pricing Strategies: the Japanese Experience. The Geneva Papers on Risk and Insurance-Issues and Practice, 30(2), 312-326. http://doi.org/10.1057/palgrave. gpp. 2510028

Shiu, Y. (2004). Determinants of United Kingdom General Insurance Company Performance. British Actuarial Journal, 10(5), 1079-1110. https://doi.org/10.1017/ S1357321700002968

\section{Appendix}

\begin{tabular}{|c|c|c|c|c|}
\hline Authors & Sample & Period & Methodology* & $\begin{array}{c}\text { Significant profitability } \\
\text { determinants }\end{array}$ \\
\hline $\begin{array}{l}\text { Browne, Carson, \& } \\
\text { Hoyt (2001) }\end{array}$ & USA & 1985-1995 & $\begin{array}{l}\text { Dynamic panel } \\
\text { regression }\end{array}$ & $\begin{array}{l}\text { interest rate, } \\
\text { personal income, } \\
\text { unemployment and } \\
\text { stock market movements } \\
\end{array}$ \\
\hline Shiu (2004) & UK & 1986-1999 & $\begin{array}{l}\text { Panel } \\
\text { Regression }\end{array}$ & $\begin{array}{l}\text { liquidity, unexpected inflation, } \\
\text { interest rate and underwriting } \\
\text { profit }\end{array}$ \\
\hline $\begin{array}{l}\text { Liebenberg \& } \\
\text { Sommer (2008) }\end{array}$ & USA & 1995-2004 & $\begin{array}{l}\text { OLS and } \\
\text { treatment } \\
\text { effects model }\end{array}$ & $\begin{array}{l}\text { diversification affects ROA } \\
\text { and ROE; mutual insurers } \\
\text { are less profitable than stock } \\
\text { insurers }\end{array}$ \\
\hline $\begin{array}{l}\text { Berry-Stoelzle \& } \\
\text { Song (2015) }\end{array}$ & USA & 1995-2004 & $\begin{array}{l}\text { OLS and } \\
\text { treatment } \\
\text { effects model }\end{array}$ & $\begin{array}{l}\text { diversification does not } \\
\text { destroy the value of the firm } \\
\text { in general }\end{array}$ \\
\hline $\begin{array}{l}\text { Chen \& Wong } \\
\text { (2004) }\end{array}$ & $\begin{array}{l}\text { Japan, } \\
\text { Singapore, } \\
\text { Malaysia, } \\
\text { Taiwan }\end{array}$ & $\begin{array}{l}\text { Different } \\
\text { timeframes }\end{array}$ & $\begin{array}{l}\text { Fixed effects } \\
\text { model }\end{array}$ & $\begin{array}{l}\text { firm size, investment } \\
\text { performance, liquidity ratio, } \\
\text { surplus growth, combined } \\
\text { ratio, and operating margin, } \\
\text { change in asset mix, change } \\
\text { in product mix }\end{array}$ \\
\hline Lee (2014) & Taiwan & 1999-2009 & $\begin{array}{l}\text { OLS, } \\
\text { Fixed effects, } \\
\text { Random effects }\end{array}$ & $\begin{array}{l}\text { underwriting risk, reinsurance, } \\
\text { input costs, and holding-group } \\
\text { membership, leverage, } \\
\text { market share }\end{array}$ \\
\hline Dogan (2013) & Turkey & 2005-2011 & $\begin{array}{l}\text { Multiple } \\
\text { regression, } \\
\text { Correlation }\end{array}$ & $\begin{array}{l}\text { age, liquidity, loss and } \\
\text { leverage, size }\end{array}$ \\
\hline
\end{tabular}




\section{Tab. A1: Comprehensive literature survey - Part 2}

\begin{tabular}{|c|c|c|c|c|}
\hline Authors & Sample & Period & Methodology* & $\begin{array}{c}\text { Significant profitability } \\
\text { determinants }\end{array}$ \\
\hline Kaya (2015) & Turkey & 2006-2015 & $\begin{array}{l}\text { Pooled OLS, } \\
\text { Fixed effects, } \\
\text { Random effects }\end{array}$ & $\begin{array}{l}\text { age, loss ratio, liquidity, size } \\
\text { and premium growth }\end{array}$ \\
\hline Charumathi (2012) & India & 2008-2011 & $\begin{array}{l}\text { Pooled OLS, } \\
\text { Fixed effects, } \\
\text { Random effects }\end{array}$ & $\begin{array}{l}\text { leverage, premium growth, } \\
\text { and equity, size and liquidity }\end{array}$ \\
\hline Jerene (2016) & India & 2006-2016 & $\begin{array}{l}\text { Pooled OLS, } \\
\text { Fixed effects, } \\
\text { Random effects }\end{array}$ & $\begin{array}{l}\text { capital adequacy, GDP, } \\
\text { liquidity and inflation }\end{array}$ \\
\hline $\begin{array}{l}\text { Hrechaniuk et al. } \\
\text { (2007) }\end{array}$ & $\begin{array}{l}\text { Spain, Lithuania, } \\
\text { and Ukraine }\end{array}$ & $\begin{array}{l}\text { Different } \\
\text { timeframes }\end{array}$ & Fixed effects & $\begin{array}{l}\text { loss ratio, } \\
\text { growth of written premium }\end{array}$ \\
\hline Kozak (2011) & Poland & 2002-2009 & $\begin{array}{l}\text { Panel } \\
\text { regression }\end{array}$ & $\begin{array}{l}\text { portfolio restructuring, gross } \\
\text { premium growth, cost cutting } \\
\text { strategy, internationalization, } \\
\text { and GDP }\end{array}$ \\
\hline Ortyński (2016) & Poland & 2006-2013 & $\begin{array}{l}\text { WLS, panel } \\
\text { intergroup } \\
\text { estimation }\end{array}$ & $\begin{array}{l}\text { size, underwriting activity and } \\
\text { operating expenses }\end{array}$ \\
\hline $\begin{array}{l}\text { Pervan \& Pavic } \\
\text { Kramaric (2010) }\end{array}$ & Croatia & 2003-2009 & $\begin{array}{l}\text { Dynamic panel } \\
\text { regression } \\
\text { model }\end{array}$ & $\begin{array}{l}\text { lagged profit, ownership } \\
\text { structure, operative efficiency } \\
\text { (expense ratio) and inflation }\end{array}$ \\
\hline $\begin{array}{l}\text { Curak, Pepur, \& } \\
\text { Popovski (2011) }\end{array}$ & Croatia & 2004-2009 & $\begin{array}{l}\text { Panel } \\
\text { regression } \\
\text { model }\end{array}$ & $\begin{array}{l}\text { size, underwriting risk, } \\
\text { inflation and equity returns }\end{array}$ \\
\hline $\begin{array}{l}\text { Curak, Utrobicic, \& } \\
\text { Kovac (2014) }\end{array}$ & Croatia & 2006-2011 & $\begin{array}{l}\text { Panel } \\
\text { regression } \\
\text { model }\end{array}$ & $\begin{array}{l}\text { leverage, size, ROI, } \\
\text { ownership, and the non-life } \\
\text { share in total market }\end{array}$ \\
\hline $\begin{array}{l}\text { Pervan, Curak, \& } \\
\text { Marjanovic (2012) }\end{array}$ & $\begin{array}{l}\text { Bosnia and } \\
\text { Herzegovina }\end{array}$ & 2005-2010 & Panel GMM & $\begin{array}{l}\text { relative market position, past } \\
\text { business performances and } \\
\text { age; the domestic companies } \\
\text { are outperformed by the } \\
\text { foreign ones }\end{array}$ \\
\hline $\begin{array}{l}\text { Burca \& Batrinca } \\
\text { (2014) }\end{array}$ & Romania & 2008-2012 & $\begin{array}{l}\text { Fixed effects } \\
\text { and random } \\
\text { effects }\end{array}$ & $\begin{array}{l}\text { solvency margin, retention } \\
\text { ratio, size, leverage and } \\
\text { underwriting risks }\end{array}$ \\
\hline $\begin{array}{l}\text { Kocovic, Paunovic, } \\
\& \text { Jovovic (2014) }\end{array}$ & Serbia & 2006-2013 & Fixed effects & $\begin{array}{l}\text { retention rate, leverage, } \\
\text { combined ratio, company } \\
\text { size, investment ratio, and } \\
\text { premium growth }\end{array}$ \\
\hline
\end{tabular}

Note: * Some authors have not provided the regression method explicitly. 
Tab. A2: Selected firm-level business indicators (2008-2016, average, \%)

\begin{tabular}{l|r|r|r|r|r|r|c}
\multicolumn{1}{c|}{ Company } & \multicolumn{1}{c|}{ ROA } & \multicolumn{1}{c|}{ ROE } & ROTP & LIQUID & RISK_EXP & MS_ASSET $^{*}$ & MS_PREMIUM** $^{*}$ \\
\hline AMC & 2.17 & 11.78 & 3.43 & 19.22 & 7.46 & 2.28 & 2.83 \\
\hline AXA LIFE & -9.05 & -12.69 & -43.42 & 21.06 & 116.19 & 0.46 & 0.20 \\
\hline $\begin{array}{l}\text { DDOR NOVI SAD } \\
\text { INSURANCE }\end{array}$ & 1.80 & 11.26 & 3.02 & 11.73 & 22.54 & 12.61 & 15.40 \\
\hline $\begin{array}{l}\text { DDOR NOVI SAD } \\
\text { REINSURANCE }\end{array}$ & 1.20 & 3.00 & 2.89 & $3,333.30$ & 17.47 & 0.18 & 0.05 \\
\hline $\begin{array}{l}\text { DELTA DJENERALI } \\
\text { INSURANCE }\end{array}$ & 3.21 & 50.61 & 7.58 & 10.04 & 74.20 & 19.26 & 19.35 \\
\hline $\begin{array}{l}\text { DELTA DJENERALI } \\
\text { REINSURANCE }\end{array}$ & 3.80 & 13.24 & 5.37 & 2.99 & 1.04 & 1.56 & 4.51 \\
\hline DUNAS INSURANCE & 1.86 & 79.67 & 3.24 & 8.80 & 15.94 & 22.71 & 26.40 \\
\hline $\begin{array}{l}\text { DUNAV } \\
\text { REINSURANCE }\end{array}$ & 5.01 & 28.35 & 4.28 & 3.58 & 3.97 & 2.75 & 5.94 \\
\hline $\begin{array}{l}\text { ENERGOPROJEKT } \\
\text { GARANT }\end{array}$ & 10.09 & 17.25 & 60.46 & 54.15 & 7.53 & 0.81 & 0.25 \\
\hline $\begin{array}{l}\text { GLOBUS } \\
\text { INSURANCE }\end{array}$ & 20.32 & 18.07 & 64.37 & 22.27 & 11.68 & 0.81 & 0.51 \\
\hline GRAWE INSURANCE & 2.50 & 42.51 & 13.21 & 39.56 & 352.54 & 9.65 & 3.70 \\
\hline $\begin{array}{l}\text { MERKUR } \\
\text { INSURANCE }\end{array}$ & -3.67 & -5.83 & -8.33 & 5.54 & 131.25 & 0.98 & 0.79 \\
\hline $\begin{array}{l}\text { MILENIJUM } \\
\text { INSURANCE }\end{array}$ & -2.37 & -4.77 & -3.41 & 15.24 & 0.74 & 1.72 & 2.24 \\
\hline SAVA LIFE & -11.22 & -10.81 & -98.80 & 59.80 & 78.02 & 0.32 & 0.03 \\
\hline SAVA NON-LIFE & -2.16 & -0.59 & 11.87 & 2.21 & 2.10 & 2.12 \\
\hline $\begin{array}{l}\text { UNIQA LIFE } \\
\text { UNIQA NON-LIFE }\end{array}$ & -2.02 & -8.51 & -3.30 & 8.77 & 4.44 & 4.01 & 4.67 \\
\hline $\begin{array}{l}\text { WINER } \\
\text { REINSURANCE }\end{array}$ & 1.90 & 9.11 & 3.62 & 94.31 & 1.17 & 2.04 & 0.80 \\
\hline WIENER STADTISHE & 0.99 & 15.16 & 3.29 & 11.71 & 365.93 & 12.21 & 8.62 \\
\hline
\end{tabular}

Source: own calculation based on the NBS Insurance Sector Reports

Note: * Market share in total asset; ${ }^{* *}$ Market share in total premium. 


\section{Finance}

\section{Tab. A3: Descriptive statistics}

\begin{tabular}{l|c|r|r|r|r|r|r|r|r}
$\begin{array}{l}\text { Statistics/ } \\
\text { Variable }\end{array}$ & ROA & \multicolumn{1}{|c|}{ ROE } & \multicolumn{1}{c|}{ ROTP } & LIQUID & LOSS_RATIO & MPR & PRODUCT & RISK_EXP & SIZE \\
\hline Mean & 1.41674 & 14.2657 & 0.90357 & 22.6646 & 26.77614 & 5.17150 & 956.1479 & 83.71673 & 12.7237 \\
\hline Median & 1.29967 & 9.00773 & 2.20345 & 9.85489 & 27.61063 & 1.94714 & 26.39225 & 9.609923 & 13.8842 \\
\hline Maximum & 81.1490 & 412.477 & 288.786 & 831.783 & 87.76027 & 94.9222 & 62306.89 & 1954.333 & 17.2122 \\
\hline Minimum & -35.821 & -86.733 & -335.60 & 0.95605 & 0.00000 & 0.00000 & 0.00000 & 0.00000 & 6.17419 \\
\hline Std. Dev. & 11.1202 & 40.9331 & 50.6013 & 71.6758 & 20.21816 & 9.63814 & 5129.785 & 190.1368 & 3.26954 \\
\hline Skewness & 3.21856 & 5.93949 & -1.1753 & 9.5963 & 0.257061 & 5.54020 & 10.78445 & 6.343119 & -0.54498 \\
\hline Kurtosis & 25.9240 & 57.1339 & 24.7753 & 104.299 & 2.206443 & 48.0543 & 128.0891 & 59.36863 & 1.90589 \\
\hline Sum & 229.513 & 2311.04 & 146.379 & 3671.66 & 4337.735 & 837.784 & 154896 & 13562.11 & 2061.25 \\
\hline Sum Sq. Dev. & 19909.2 & 269759 & 412239 & 827125. & 65812.61 & 14955.9 & $4.24 E+09$ & 5820471 & 1721.07 \\
\hline & & & & & & & \\
\hline
\end{tabular}

Source: own calculation based on the NBS Insurance Sector Reports

Note: * Market share in total asset; ${ }^{* *}$ Market share in total premium.

\begin{tabular}{l|c|c|c|c|c|c|c|c|c} 
Tab. A4: & Correlation matrix \\
\multicolumn{1}{c|}{ Variable } & ROA & ROE & ROTP & LIQUID & LOSS_RATIO & MPR & PRODUCT & RISK_EXP & SIZE \\
\hline ROA & 1.00000 & 0.37868 & 0.80769 & 0.02336 & -0.02585 & 0.02370 & 0.02303 & -0.06835 & -0.10738 \\
\hline ROE & 0.37868 & 1.00000 & 0.27966 & -0.01377 & 0.06839 & 0.29664 & 0.01602 & 0.02833 & 0.09942 \\
\hline ROTP & 0.80769 & 0.27966 & 1.00000 & 0.01967 & 0.03671 & 0.02661 & 0.00845 & -0.03205 & -0.09293 \\
\hline LIQUID & 0.02336 & -0.01377 & 0.01967 & 1.00000 & -0.13893 & -0.09708 & -0.04198 & -0.02487 & -0.04029 \\
\hline LOSS_RATIO & -0.02585 & 0.06839 & 0.03671 & -0.13893 & 1.00000 & 0.07364 & -0.12055 & 0.00073 & 0.27287 \\
\hline MPR & 0.02370 & 0.29664 & 0.02661 & -0.09708 & 0.07364 & 1.00000 & 0.70433 & -0.02438 & 0.18056 \\
\hline PRODUCT & 0.02303 & 0.01602 & 0.00845 & -0.04198 & -0.12055 & 0.70433 & 1.00000 & -0.06430 & -0.03999 \\
\hline RISK_EXP & -0.06835 & 0.02833 & -0.03205 & -0.02487 & 0.00073 & -0.02438 & -0.06430 & 1.00000 & 0.12079 \\
\hline SIZE & -0.10738 & 0.09942 & -0.09293 & -0.04029 & 0.27287 & 0.18056 & -0.03999 & 0.12079 & 1.00000 \\
\hline
\end{tabular}

Source: own calculation based on the NBS Insurance Sector Reports 


\begin{tabular}{l|c|c|c|c|c|c|c|c|c} 
Tab. A5: & Variance-covariance matrix \\
\multicolumn{1}{c|}{ Variable } & ROA & ROE & ROTP & LIQUID & LOSs_RATIO & MPR & PRODUCT & RISK_EXP & SIZE \\
\hline ROA & 122.897 & 171.3079 & 451.6825 & 18.5058 & -5.7755 & 2.5245 & 1305.4338 & -143.6234 & -3.8802 \\
\hline ROE & 171.308 & 1665.182 & 575.6745 & -40.1510 & 56.2538 & 116.3063 & 3343.9066 & 219.1572 & 13.2229 \\
\hline ROTP & 451.683 & 575.6745 & 2544.685 & 70.8945 & 37.3233 & 12.8957 & 2178.6355 & -306.4760 & -15.280 \\
\hline LIQUID & 18.5058 & -40.1510 & 70.8945 & 5105.7138 & -200.0929 & -66.6537 & -15339.8731 & -336.7971 & -9.3841 \\
\hline LOSS_ & -5.7755 & 56.2538 & 37.3233 & -200.0929 & 406.2507 & 14.2620 & -12425.9559 & 2.7923 & 17.9266 \\
\hline RATIO & 2.5245 & 116.3063 & 12.8957 & -66.6537 & 14.2620 & 92.3202 & 34608.2066 & -44.4096 & 5.6548 \\
\hline MPR & 1305.43 & 3343.91 & 2178.64 & -15339.87 & -12425.96 & 34608.21 & 26152254.25 & -62327.25 & -666.60 \\
\hline PRODUCT & -143.623 & 219.1572 & -306.476 & -336.7971 & 2.7923 & -44.4096 & -62327.2520 & 35928.833 & 74.6277 \\
\hline RISK_EXP & -3.8802 & 13.2229 & -15.2803 & -9.3841 & 17.9266 & 5.6548 & -666.5978 & 74.6277 & 10.6239 \\
\hline SIZE & & & & $5046: 0$ & &
\end{tabular}

Source: own calculation based on the NBS Insurance Sector Reports

\section{Tab. A6: Stationarity testing}

Part 1: Level

\begin{tabular}{c|c|c|c|c|c|c|c|c|c|c|c|c|c|c|c|c|c|c}
\hline & \multicolumn{2}{|c|}{ ROA } & \multicolumn{2}{c|}{ ROE } & \multicolumn{2}{c|}{ ROTP } & \multicolumn{2}{c|}{ LIQIDITY } & \multicolumn{2}{c|}{ LOSS } & \multicolumn{2}{c|}{ MPR } & \multicolumn{2}{c|}{ PRODUCT } & \multicolumn{2}{c|}{ RISK } & \multicolumn{2}{c}{ SIZE } \\
\hline TEST & Stat. & $\mathbf{P}^{*}$ & Stat. & $\mathbf{P}^{*}$ & Stat. & $\mathbf{P}^{*}$ & Stat. & $\mathbf{P}^{*}$ & Stat. & $\mathbf{P}^{*}$ & Stat. & $\mathbf{P}^{*}$ & Stat. & $\mathbf{P}^{*}$ & Stat. & $\mathbf{P}^{*}$ & Stat. $^{P^{*}}$ \\
\hline Test 1 & -10.9 & 0.00 & -1.7 & 0.04 & -5.0 & 0.00 & 340.4 & 1.00 & -3.7 & 0.00 & -4.3 & 0.00 & -1879 & 0.00 & -0.9 & 0.20 & 1.8 & 0.96 \\
\hline Test 2 & -3.5 & 0.00 & -1.7 & 0.04 & -2.5 & 0.01 & -0.1 & 0.47 & -1.4 & 0.09 & -0.9 & 0.17 & -999.6 & 0.00 & 0.4 & 0.65 & 3.0 & 1.00 \\
\hline Test 3 & 77.8 & 0.00 & 64.5 & 0.00 & 67.8 & 0.00 & 38.9 & 0.34 & 51.0 & 0.05 & 42.3 & 0.22 & 291.6 & 0.00 & 32.5 & 0.64 & 6.5 & 1.00 \\
\hline Test 4 & 98.3 & 0.00 & 108.0 & 0.00 & 100.0 & 0.00 & 99.2 & 0.00 & 106.9 & 0.00 & 77.9 & 0.00 & 120.7 & 0.00 & 81.0 & 0.00 & 7.5 & 1.00 \\
\hline
\end{tabular}

\begin{tabular}{|c|c|c|c|c|c|c|c|c|c|c|c|c|c|c|}
\hline \multicolumn{15}{|c|}{ Part 2: First-difference/Stationarity diagnostics } \\
\hline \multicolumn{9}{|c|}{ First-Difference } & \multicolumn{6}{|c|}{ Stationary diagnostics } \\
\hline & \multicolumn{2}{|c|}{ LIQUIDITY } & \multicolumn{2}{|c|}{ MPR } & \multicolumn{2}{|c|}{ RISK } & \multicolumn{2}{|c|}{ SIZE } & \multirow{2}{*}{\begin{tabular}{|l|} 
VAR \\
ROA
\end{tabular}} & \multirow{2}{*}{$\begin{array}{c}\text { Level } \\
\text { Stationary }\end{array}$} & \multirow{2}{*}{\begin{tabular}{|l|} 
First-Diff. \\
Stationary \\
\end{tabular}} & \multirow{2}{*}{\begin{tabular}{|l|} 
VAR \\
MPR
\end{tabular}} & \multirow{2}{*}{$\begin{array}{c}\text { Level } \\
\begin{array}{c}\text { Non- } \\
\text { stationary }\end{array}\end{array}$} & \multirow{2}{*}{$\begin{array}{l}\text { First-Diff. } \\
\text { Stationary }\end{array}$} \\
\hline TEST & Stat. & $\mathbf{P}^{*}$ & Stat. & $\mathbf{P}^{*}$ & Stat. & $P^{*}$ & Stat. & $\mathbf{P}^{*}$ & & & & & & \\
\hline Test 1 & 116 & 1.00 & -5.5 & 0.0 & -3.9 & 0.00 & -6.8 & 0.000 & ROE & Stationary & Stationary & PRODUCT & Stationary & Stationary \\
\hline Test 2 & -2.3 & 0.01 & -2.8 & 0.0 & -2.7 & 0.00 & -2.7 & 0.003 & $R O P$ & Stationary & Stationary & RISK & $\begin{array}{c}\text { Non- } \\
\text { stationary }\end{array}$ & Stationary \\
\hline Test 3 & 66.7 & 0.00 & 69.9 & 0.0 & 68.0 & 0.00 & 69.0 & 0.001 & LIQUIDITY & $\begin{array}{c}\text { Non- } \\
\text { stationary }\end{array}$ & Stationary & SIZE & $\begin{array}{c}\text { Non- } \\
\text { stationary }\end{array}$ & Stationary \\
\hline Test 4 & 172. & 0.00 & 196.3 & 0.0 & 195.0 & 0.00 & 164.6 & 0.000 & LOSS & Stationary & Stationary & & ........ & -..-- \\
\hline \multicolumn{10}{|c|}{ Test 1: Levin, Lin \& Chu test } & \multicolumn{5}{|c|}{ Test 2: Im, Pesaran and Shin W-stat } \\
\hline \multicolumn{10}{|c|}{ Test 3: ADF - Fisher Chi-square } & \multicolumn{5}{|c|}{ Test 4: PP - Fisher Chi-square } \\
\hline
\end{tabular}

Source: own calculation

Note: * Probabilities for Fisher tests are computed using an asymptotic Chi-square distribution. All other tests assume asymptotic normality. 
Finance

Fig. A1:

Residual diagnostics (OLS)

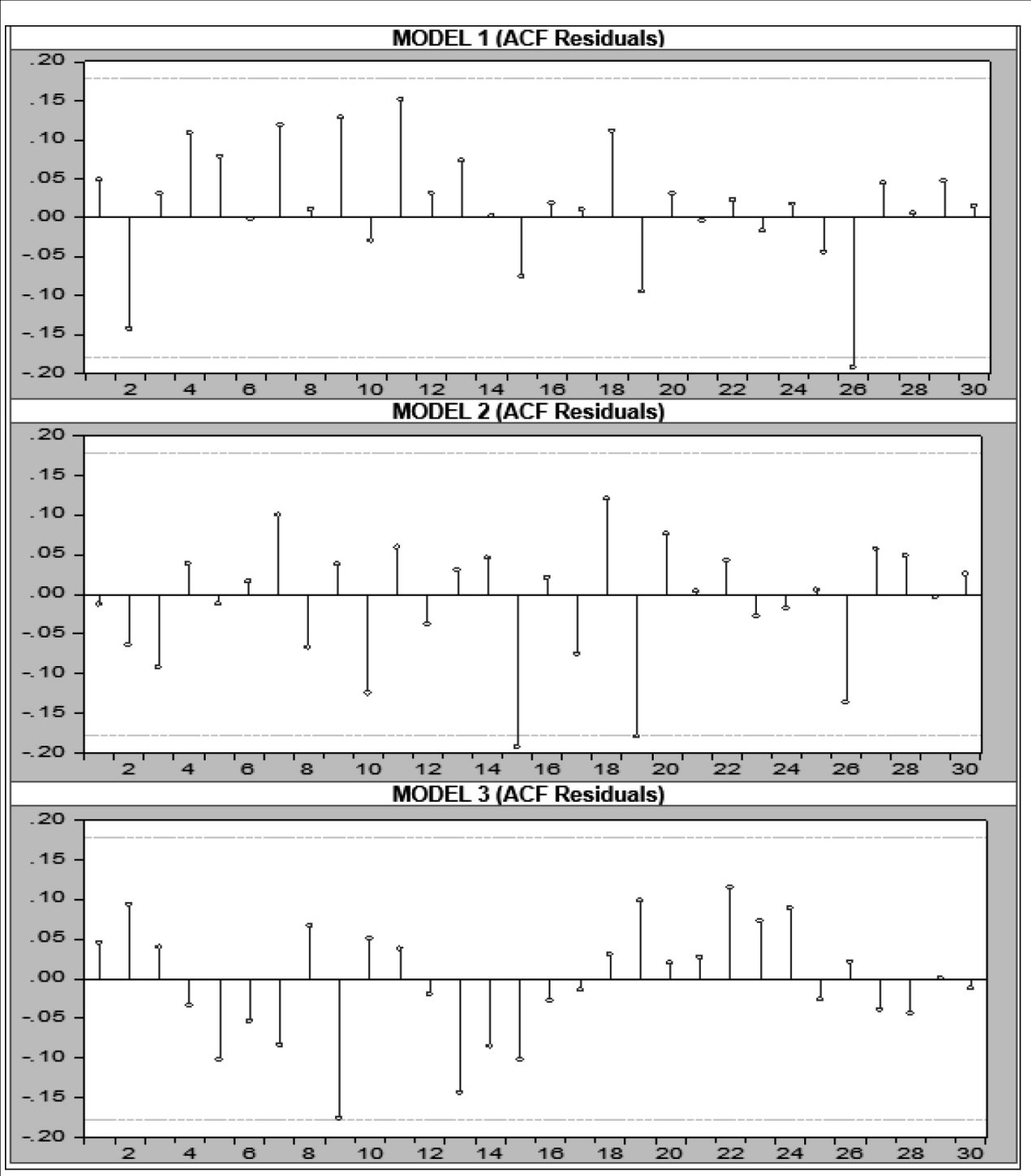

Source: own calculation 


\section{Tab. A7:}

\section{Wald test results}

\begin{tabular}{|c|c|c|c|c|c|c|c|c|c|c|c|}
\hline \multicolumn{4}{|c|}{ MODEL 1 (ROA) } & \multicolumn{4}{|c|}{ MODEL 2 (ROE) } & \multicolumn{4}{|c|}{ MODEL 3 (ROTP) } \\
\hline T-stat & Value & df & Prob. & T-stat & Value & df & Prob. & T-stat & Value & df & Prob. \\
\hline F-stat & 117.0828 & $(8,351)$ & 0.0000 & F-stat & 114.0163 & $(8,331)$ & 0.0000 & F-stat & 24.5814 & $(8,331)$ & 0.0000 \\
\hline Chi-sq & 936.6625 & 8 & 0.0000 & Chi-sq & 912.1301 & 8 & 0.0000 & Chi-sq & 196.6512 & 8 & 0.0000 \\
\hline \multicolumn{4}{|c|}{ Null hypothesis: } & \multicolumn{4}{|c|}{ Null hypothesis: } & \multicolumn{4}{|c|}{ Null hypothesis: } \\
\hline \multicolumn{4}{|c|}{$C(1)=C(2)=C(3)=C(4)=C(5)=C(6)=C(7)=C(8)=0$} & \multicolumn{4}{|c|}{$C(1)=C(2)=C(3)=C(4)=C(5)=C(6)=C(7)=C(8)=0$} & \multicolumn{4}{|c|}{$C(1)=C(2)=C(3)=C(4)=C(5)=C(6)=C(7)=C(8)=0$} \\
\hline \multicolumn{4}{|c|}{ Null hypothesis summary: } & \multicolumn{4}{|c|}{ Null hypothesis summary: } & \multicolumn{4}{|c|}{ Null hypothesis summary: } \\
\hline \multicolumn{2}{|c|}{ Norm. restrict. $(=0)$} & Value & Std. Err. & \multicolumn{2}{|c|}{ Norm. restrict. $(=0)$} & Value & Std. Err. & \multicolumn{2}{|c|}{ Norm. restrict. $(=0)$} & Value & Std. Err. \\
\hline \multicolumn{2}{|c|}{$C(1)$} & 0.0066 & 0.0021 & \multicolumn{2}{|c|}{$C(1)$} & 0.0067 & 0.0021 & \multicolumn{2}{|c|}{$C(1)$} & -0.4801 & 0.2880 \\
\hline \multicolumn{2}{|c|}{$C(2)$} & 0.0004 & 0.0004 & \multicolumn{2}{|c|}{$C(2)$} & 0.0004 & 0.0004 & \multicolumn{2}{|c|}{$C(2)$} & 0.0002 & 0.0008 \\
\hline \multicolumn{2}{|c|}{$C(3)$} & 0.0001 & 0.0002 & \multicolumn{2}{|c|}{$C(3)$} & 0.0001 & 0.0002 & \multicolumn{2}{|c|}{$C(3)$} & -0.0001 & 0.0008 \\
\hline \multicolumn{2}{|c|}{$C(4)$} & 0.2219 & 0.0323 & \multicolumn{2}{|c|}{$C(4)$} & 0.2191 & 0.0333 & \multicolumn{2}{|c|}{$C(4)$} & 0.2142 & 0.0735 \\
\hline \multicolumn{2}{|c|}{$C(5)$} & -0.0039 & 0.0095 & \multicolumn{2}{|c|}{$C(5)$} & -0.0072 & 0.0099 & \multicolumn{2}{|c|}{$C(5)$} & -0.0106 & 0.0227 \\
\hline \multicolumn{2}{|c|}{$C(6)$} & 0.3873 & 0.0396 & \multicolumn{2}{|c|}{$C(6)$} & 0.4090 & 0.0409 & \multicolumn{2}{|c|}{$C(6)$} & 0.3859 & 0.0936 \\
\hline \multicolumn{2}{|c|}{$C(7)$} & -0.0003 & 0.0002 & \multicolumn{2}{|c|}{$C(7)$} & -0.0003 & 0.0002 & & 7) & -0.0001 & 0.0008 \\
\hline & (8) & -0.0235 & 0.0065 & & & -0.0222 & 0.0066 & & 8) & 0.0576 & 0.0342 \\
\hline Restr & tions are lin & ar in coef & icients. & Restri & ions are lin & ear in coe & ficients. & Restric & ions are lin & ear in coe & icients. \\
\hline
\end{tabular}

Source: own calculation

Note: * Probabilities for Fisher tests are computed using an asymptotic Chi-square distribution. All other tests assume asymptotic normality. 